\title{
The Content of Heavy Metals in Waste as an Indicator Determining the Possibilities of Their Agricultural Use
}

\author{
Dawid Łapiński", Józefa Wiater¹, Ewa Szatyłowicz' \\ 1 Bialystok University of Technology ul. Wiejska 45A, 15-351 Białystok, Poland \\ * Corresponding author's e-mail: d.lapinski@pb.edu.pl
}

\begin{abstract}
The aim of the study was to evaluate the available waste in view of the heavy metals and fractions thereof. Three waste materials were analyzed in the work, namely dried, granular sludge, digestate from agricultural biogas plant and ash after combustion of biomass from the combined heat and power plant, in terms of the content of heavy metals in them. Their mobility through fractional analysis was determined and the possibilities of their agricultural use were assessed. The analyzed waste was varied due to the $\mathrm{pH}$. Biomass ashes had the highest $\mathrm{pH}$ and it was alkaline. The $\mathrm{pH}$ of the dried precipitate was neutral and digestate was slightly alkaline. In the analyzed wastes, the content of permissible concentrations of heavy metals determined in the Regulation of the Minister of the Environment was not exceeded. The content of individual elements varied and depends on the type of waste tested. The conducted sequential analysis showed that various metal fractions are present in the tested wastes. The content of heavy metals in individual factions was varied and the content of mobile and potentially mobile fractions, i.e. metals of fractions I and II, was lower compared to the non-mobile fractions III and IV.
\end{abstract}

Keywords: heavy metals, digestate, ash, dried sludge

\section{INTRODUCTION}

One of the main factors of negative human impact on the natural environment is the release of heavy metals, which pose a serious threat to living organisms. Their origin is natural and anthropogenic. They easily infiltrate into the air, water and soil as a result of combustion of fossil fuels, ore processing, etc., and then into the food chain of plants and animals [Gruca-Królikowska et al, 2006, Li et, 2008]. They exert toxic, mutagenic and carcinogenic effect on the human body [Bień, 2002]. Their content and paths of migration in the environment as well as waste products produced by man are being examined more and more often [Rosik-Dulewska, 2009]. The most important legal act in Poland regarding waste management is the Waste Act of 14 December 2012, as amended from 24 November 2017. According to the literature and legal acts in force, it can be said that "recovery" is a preferred way of waste management for ecological and economic reasons [Sadecka et al. 2011]. Wastes can be a valuable and relatively cheap source of nutrients necessary for the plant; moreover, they can favorably affect certain soil properties under the condition that certain standards are met, including the heavy metal content not only in general form, but also by determining their fractions on the basis of which the rate of heavy metals originating from waste can be determined. This is very important information for agricultural practice, it allows to assess the rate of transfer of these elements to the soil solution and, as a result, their uptake by plants. While applying the waste to the soil, excess heavy metals can cause changes in soil fertility and reduce the size and quality of crop plants [Siuta, 2013, Kalembasa et al. 2003]. The aim of the study was to evaluate the available waste in terms of the heavy metals and fractions thereof. 


\section{MATERIALS AND METHODS}

Three types of waste were selected for the study:

- Dried sewage sludge from municipal wastewater treatment plants

- Digestate from an agricultural biogas plant

- Ash from biomass burning from a combined heat and power plant

The dried sludge in the form of granules was taken from a mechanical and biological wastewater treatment plant where the actual P.E. (population equivalent) of the facility is around 360,000, out of which 56,200 are in the industry. The maximum treatment plant can handle the P.E of 450,000 . The projected capacity of the facility is $100,000 \mathrm{~m}^{3} / \mathrm{d}$. The reduction of incoming pollutants is estimated at 95\% BOD5, 90\% total nitrogen, $96.8 \%$ total phosphorus and $85 \%$ total suspension. Operation of the sewage treatment plant is based on activated sludge technology with a division into three nodes: mechanical, biological and processing of sludge. Sewage sludges are subjected to concentration and subsequent fermentation in four Separated Fermentation Chambers. The process takes place over 25-30 days at a temperature of $35-37^{\circ} \mathrm{C}$. The sewage treatment plant is able to process about $400 \div 700 \mathrm{~m}^{3}$ of sediment after compaction and uses the biogas produced in the process of methane fermentation in the form of electric current. Finally, the sediments are dewatered and some are thermally dried and transformed into granules which are used for fertilizing and soil remediation. Every year, 6800 tons of dry sludge mass is produced in the sewage. In 2012, the granules from the Treatment Plant obtained an appropriate certificate on the basis of a decision issued by the Ministry of Agriculture and Rural Development, which allows the placing an organic fertilizer under the name "Granbial" on the market. The granulate produced in the treatment plant can be used for fertilizing agricultural plants, such as: cereals, maize, rape, industrial plants. It can also be applied for fertilizing lawns, ornamental plants such as trees, shrubs and flowers [Wiater 2014].

The digestate was taken from an agricultural biogas plant with an installed electrical capacity of $1 \mathrm{MW}$ and an annual capacity of an installation for the production of agricultural biogas equal to $4380000 \mathrm{~m}^{3}$ / year. The biogas plant operates in a continuous system and was established on $20 / 01 / 2014$. The substrate consists mainly of maize silage, slurry as well as poultry manure and potato industry waste. The first two substrates come from local farms with an area of 556 hectares (cultivation and breeding pigs) and from the ownership land of biogas plants with an area of 321 hectares (cultivation: maize, rapeseed and grain). The potato pulp is produced by PEPEES potato processing plants; the company processes about 200,000 tons of starch and edible potatoes annually. The input to the biogas plant can be enriched with vegetable products and by-products of the meat and fruit industry. It is assumed that the daily system demand is about 42-44 tons of substrate. The substrate composition can be modified every day, but the materials used must have the appropriate energy characteristics. The batch is fermented in fermenters at $38-43^{\circ} \mathrm{C}$, which results in the production of biogas. The heat generated is used for the biogas plant own needs, which account for about $8 \%$ of total production, while the electricity is switched on to the grid. [Wiater 2017, Szatyłowicz et al. 2016]

The ash from the biomass combustion was taken from the municipal heat and power plant. Generation of electricity is carried out using steam boilers, two coal-fired and two biomass ones. Annually, the heat and power plant produces approximately 3.8 million GJ of heat. Biomass boilers are new devices of the combined heat and power plant because the first one started to work in 2008, and the second in 2012. Specially designed hearths, so-called fluidized beds (BFB) are the basic element of the biomass boiler, which was created as a result of the conversion of the existing OP-140 boiler. The boiler burns raw biomass, the humidity of which varies in the range of $30-55 \%$. The composition of the biomass was $80 \%$ wood chips and the remaining $20 \%$ was agro biomass, consisting mainly of energy willow.

The samples was taken three times from May to July 2018 and their basic properties were determined, using:

- $\mathrm{pH}$ - potentiometric method

- dry mass - weight method

- dry organic mass - loss on ignition

In the waste, the contents of heavy metals and their fractions were determined with the ASA method on the atomic absorption spectrometer Thermo Scientific iCE3400 with electrothermal atomization. In order to determine the content of heavy metals, the samples were subjected to mineralization in concentrated nitric acid using 
a Milestone Ethos Easy microwave mineralizer, in order to determine the metal fraction, the BCR modified sequential extraction was used:

- Fraction I: the sample was extracted with $0.11 \mathrm{M}$ acetic acid $\mathrm{CH}_{3} \mathrm{COOH}$. In this way, the fractions of metals that are available and associated with carbonates were obtained.

- Fraction II: the sample was extracted with a 0.5 molar solution of hydroxylamine hydrochloride $\mathrm{NH}_{2} \mathrm{OH} \cdot \mathrm{HCl}$. This gave fractions reducible metals associated with amorphous iron and manganese oxides (Fraction II).

- Fraction III: the sample was extracted with $30 \%$ hydrogen peroxide $\mathrm{H}_{2} \mathrm{O}_{2}$ and 1 molar ammonium $\mathrm{CH}_{3} \mathrm{COONH}_{4}$. The metal fractions associated with the organic substance were thus extracted.

- Fraction IV: the residual fraction was calculated as the difference of the sum of three fractions from the general form.

The analyses were carried out in accordance with the current standards or based on the analytical methodology commonly used and recommended by the scientific literature. Each determination was performed three times and the result was averaged.

\section{RESULTS}

The obtained test results are presented in Tables $1-3$. The analyzed waste is varied due to the $\mathrm{pH}$. The highest $\mathrm{pH}$ characterized ash from biomass and it was alkaline. The $\mathrm{pH}$ of the dried precipitate was neutral, and digestate was slightly alkaline (Table 1).

Due to the drying and combustion process, sludge and ash deposits were characterized by a very high dry matter content above $95 \%$, while the digestate, due to its liquid consistency, had only $7 \%$ of dry matter. The lowest content of organic matter was recorded in the digestate $23.40 \% \mathrm{~d} . \mathrm{m}$, ash from incineration plants had $31.58 \%$ d.m. and the highest value was found in dried sludge, $42.02 \% \mathrm{~d} . \mathrm{m}$. The content of organic matter in the sediments was lower than reported by Milik et al.
[2016] and Kazanowska and Szaciło [2012]. An organic substance has a significant impact on the binding of heavy metals in waste samples and can decide on their mobility. The ash from biomass combustion contained over $30 \%$ d.m. organic substance. Rajczyk et al. [2013], report that the loss of ash incineration, as a rule, exceeds $10 \%$ which predisposes it to natural use, and limits its use in construction.

Table 2 and 3 shows the content of the metals studied per kg of dry weight of waste.

The admissible content of heavy metals in the analyzed wastes, determined in the Regulation of the Minister of Environment of February 6, 2015 was not exceeded. The content of individual elements varied and depends on the type of waste tested; therefore, it can be stated that the examined waste materials can be used for fertilization soils and plants, land reclamation, production of compost and plants for energy purposes. The sewage sludge contained the most marked metals except for lead and cadmium, most of which was in the Digestate. The content of metals in the tested sediment was arranged according to the series of $\mathrm{Cd}<\mathrm{Pb}, \mathrm{Ni}, \mathrm{Cr}<\mathrm{Zn}$. It is consistent with the value provided by Wilk and Gworek [2009].

Analyzing the composition of digestate in terms of the $\mathrm{Cd}, \mathrm{Pb}, \mathrm{Cu}, \mathrm{Zn}$ content, as compared to the composition of digestate produced in Swedish biogas plants from pig and bovine slurry, where the content of these elements was: $0.3 \mathrm{Cd} \mathrm{mg} / \mathrm{kg}$ d.m., $4.1 \mathrm{~Pb} \mathrm{mg} / \mathrm{kg}$ d.m., $113.0 \mathrm{Cu}$ $\mathrm{mg} / \mathrm{kg}$ d.m., $375 \mathrm{Zn} \mathrm{mg/kg} \mathrm{d.m.} \mathrm{[Szymańska} \mathrm{et} \mathrm{al,}$ 2011], it can be concluded that only the content of copper and chromium was lower in the examined post-ferment, while the lead content was ten times higher. Differences may be due to the type of charge used to produce biogas.

The conducted sequential analysis showed that various metal fractions are present in the tested wastes. The content of heavy metals in individual fractions varied. Zinc in the dried sludge and ash were evenly distributed in the mobile and non-mobile fractions in a percentage ratio of 50 to 50. Similar results were also obtained by Boruszko [2013] while investigating sewage sludge. On

Table 1. Basic parameters of waste

\begin{tabular}{|c|c|c|c|c|}
\hline Parameter & The dried sludge & Digestate & Ash & Unit \\
\hline $\mathrm{pH}$ & 7,39 & 8,12 & 12,87 & - \\
\hline Dry mass & 95,42 & 7,09 & 97,84 & $\%$ s.m. \\
\hline Dry organic mass & 42,02 & 23,68 & 31,58 & . \\
\hline
\end{tabular}


Table 2. Content of the general form of heavy metals

\begin{tabular}{|c|c|c|c|c|}
\hline Element studied & The dried sludge & Digestate & Ash & Unit \\
\hline $\mathrm{Zn}$ & 1524,85 & 424,70 & 852,88 & $\mathrm{mg} / \mathrm{kg} \mathrm{s} . \mathrm{m}$. \\
\hline $\mathrm{Cu}$ & 201,54 & 60,38 & 49,93 & $\mathrm{mg} / \mathrm{kg} \mathrm{s} . \mathrm{m}$. \\
\hline $\mathrm{Cr}$ & 56,83 & 20,30 & 8,30 & $\mathrm{mg} / \mathrm{kg} \mathrm{s} . \mathrm{m}$. \\
\hline $\mathrm{Ni}$ & 28,04 & 16,93 & 9,73 & $\mathrm{mg} / \mathrm{kg} \mathrm{s} . \mathrm{m}$. \\
\hline $\mathrm{Pb}$ & 20,86 & 56,15 & 3,04 & $\mathrm{mg} / \mathrm{kg} \mathrm{s} . \mathrm{m}$. \\
\hline $\mathrm{Cd}$ & 0,54 & 1,26 & 0,38 & $\mathrm{mg} / \mathrm{kg} \mathrm{s} . \mathrm{m}$. \\
\hline
\end{tabular}

Table 3. Content of heavy metal fractions

\begin{tabular}{|c|c|c|c|c|c|c|c|}
\hline \multirow{2}{*}{\multicolumn{2}{|c|}{$\begin{array}{l}\text { The element and its } \\
\text { fractions studied }\end{array}$}} & \multicolumn{2}{|c|}{ The dried sludge } & \multicolumn{2}{|c|}{ Digestate } & \multicolumn{2}{|c|}{ Ash } \\
\hline & & \multirow{2}{*}{$\frac{\mathrm{mg} / \mathrm{kg} \mathrm{d} . \mathrm{m} .}{189,41}$} & \multirow{2}{*}{$\begin{array}{c}\text { percentage } \\
\text { share }\end{array}$} & \multirow{2}{*}{$\frac{\mathrm{mg} / \mathrm{kg} \text { d.m. }}{68,59}$} & \multirow{2}{*}{$\begin{array}{c}\begin{array}{c}\text { percentage } \\
\text { share }\end{array} \\
16,15\end{array}$} & \multirow{2}{*}{$\frac{\mathrm{mg} / \mathrm{kg} \text { d.m. }}{104,39}$} & \multirow{2}{*}{$\begin{array}{c}\begin{array}{c}\text { percentage } \\
\text { share }\end{array} \\
12,24\end{array}$} \\
\hline \multirow{4}{*}{$\mathrm{Zn}$} & fraction I & & & & & & \\
\hline & fraction II & 503,21 & 33,00 & 249,14 & 58,66 & 270,40 & 31,70 \\
\hline & fraction III & 525,63 & 34,47 & 88,36 & 20,81 & 277,51 & 32,54 \\
\hline & fraction IV & 306,60 & 20,11 & 18,61 & 4,38 & 200,59 & 23,52 \\
\hline \multirow{4}{*}{$\mathrm{Cu}$} & fraction I & 15,47 & 7,68 & 4,63 & 7,67 & 8,08 & 16,18 \\
\hline & fraction II & 34,67 & 17,20 & 33,84 & 56,05 & 9,33 & 18,68 \\
\hline & fraction III & 92,52 & 45,91 & 16,51 & 27,35 & 16,86 & 33,77 \\
\hline & fraction IV & 58,88 & 29,22 & 5,40 & 8,94 & 15,66 & 31,37 \\
\hline \multirow{4}{*}{$\mathrm{Cr}$} & fraction I & 1,91 & 3,36 & 1,01 & 4,98 & 0,90 & 10,79 \\
\hline & fraction II & 1,42 & 2,50 & 5,47 & 26,95 & 0,71 & 8,50 \\
\hline & fraction III & 1,56 & 2,75 & 8,41 & 41,43 & 1,94 & 23,39 \\
\hline & fraction IV & 51,94 & 91,40 & 5,41 & 26,65 & 4,76 & 57,32 \\
\hline \multirow{4}{*}{$\mathrm{Ni}$} & fraction I & 6,35 & 22,65 & 2,36 & 13,94 & 2,78 & 28,60 \\
\hline & fraction II & 5,08 & 18,12 & 5,87 & 34,68 & 0,41 & 4,22 \\
\hline & fraction III & 5,21 & 18,58 & 3,49 & 20,62 & 3,09 & 31,73 \\
\hline & fraction IV & 11,40 & 40,66 & 5,21 & 30,75 & 3,45 & 35,44 \\
\hline \multirow{4}{*}{$\mathrm{Pb}$} & fraction I & 0,52 & 2,49 & 6,32 & 11,26 & 0,46 & 15,01 \\
\hline & fraction II & 0,85 & 4,07 & 31,45 & 56,01 & 0,40 & 12,99 \\
\hline & fraction III & 1,84 & 8,82 & 17,56 & 31,27 & 0,96 & 31,51 \\
\hline & fraction IV & 17,65 & 84,61 & 0,82 & 1,46 & 1,23 & 40,49 \\
\hline \multirow{4}{*}{$\mathrm{Cd}$} & fraction I & 0,07 & 13,52 & 0,36 & 28,41 & 0,01 & 3,78 \\
\hline & fraction II & 0,06 & 10,55 & 0,64 & 50,72 & 0,02 & 5,69 \\
\hline & fraction III & 0,13 & 24,13 & 0,14 & 10,90 & 0,07 & 17,71 \\
\hline & fraction IV & 0,28 & 51,80 & 0,13 & 9,98 & 0,27 & 72,82 \\
\hline
\end{tabular}

the other hand, in the digestate from the agricultural biogas plant, zinc was found mainly in fraction II, which accounted for $58.66 \%$ of the total.

In the case of copper, its distribution in fractions was varied into a particular one waste. In dried sewage sludge, the share of copper predominant in non-mobile fractions was mainly concentrated in fraction III, which amounted to $45.91 \%$ of the total content. The highest content of copper in the second fraction was found at 56.05\% and the lowest content was recorded in the first fraction. Mobile copper fractions predominated in the ash, about $65 \%$, and non-mobile fractions accounted for $35 \%$ of the total content. In the case of chromium, its largest content was found in dried sludge and ash. Chromium was mainly found in fraction IV and III, non-mobile fraction, and their percentage was $91.40 \%$ and $57.32 \%$ of the total content, respectively. Nickel, with respect to the other analyzed elements, was characterized by a higher share of the mobile fraction I, but its higher percentage was recorded in non-mobile fractions. In ash and dried sludge, the highest percentage was recorded in fraction IV and the share was $35.44 \%$ and $40.66 \%$, respectively. Lead in dried sewage sludge was found in $85 \%$ in the IV fraction. The highest content of lead in fraction IV was similarly observed in the case of ash; however, this waste was characterized by a significantly different share of individual fractions. Another 
distribution of lead occurred in the case of digestate from agricultural biogas plants. A larger, 67\% share of this element occurred in the mobile form, i.e. fraction I and II. In the case of cadmium in the mobile fraction, it corresponds up to $80 \%$ of the total content. However, in dried sludge and ash, cadmium occurred mainly in non-mobile fractions, approximately $76 \%$ and $90 \%$ of the total content, respectively. In the analyzed wastes of mobile and potentially mobile fractions, i.e. fractions I and II were fewer compared to non-mobile fractions III and IV. The largest share of mobile fractions in the analyzed wastes occurred in the case of digestate. In the case of the dried sewage sludge and ash from the combustion of biomass heavy metals was present in immobile form compounds. The highest content of heavy metals in the residual fraction occurred in the case of cadmium, lead and chromium. Similar relations were obtained by Gawdzik [2012] in the case of sewage sludge in which lead in fraction IV constituted as much as $75.6 \%$ share. The content of chromium and cadmium in this fraction was also high, $73.4 \%$ and $72.8 \%$, respectively.

\section{CONCLUSIONS}

On the basis on the analysis of selected wastes, the following conclusions can be drawn:

1. All analyzed waste was characterized by alkaline $\mathrm{pH}$ and therefore it can be used on light and acidic soils.

2. High content of organic matter in waste predisposes them for fertilization.

3. Low total metal content is a positive feature of waste and is classified for use in nature including agriculture.

4. The share of investigated metals in individual fractions depended on the type of waste. In the digestate, most of the metals were concentrated in the I and II (mobile) fractions and in the dried sludge and ashes in the III and IV (nonmobile) fractions. It can be concluded that the thermal treatment of waste alters the mobility of these elements.

\section{REFERENCES}

1. Bień J. 2012, Zagospodarowanie komunalnych osadów ściekowych metodami termicznymi Inżynieria i Ochrona Środowiska, 15(4), 439-449.
2. Boruszko D. 2013. Frakcjonowanie wybranych metali ciężkich w osadach ściekowych przetwarzanych metodami niskonakładowymi Rocznik Ochrona Środowiska, Tom 15, 1787-1803.

3. Boruszko D. 2011, Intensyfikacja niskonakładowych metod przeróbki komunalnych osadów ściekowych, Inżynieria Ekologiczna, 25, 189-201.

4. Chen M., Li X., Yang Q., Zeng G., Zhang Y., Liao D., Liu J., Hu J., Guo L., 2008 Total concentration and speciation of heavy metals in sewage sludge from Changasha, Zhuzhou and Xiangtan in middle-south region of China, Journal of Hazardous Materials, 160, 324-329.

5. Czekała W., Pilarski K., Dach J., Janczak D., Magdalena S., 2012 Analiza możliwości zagospodarowania pofermentu z biogazowni. Technika Rolnicza Ogrodnicza Leśna, nr 4.

6. Gawdzik J. 2012 Mobilność metali ciężkich w osadach ściekowych na przykładzie wybranej oczyszczalni ścieków. Inżynieria i Ochrona Środowiska, 15(1), 5-15.

7. Gruca-Królikowska S., Wacławek W., 2006. Metals in the environment, Part II. Effect of heavy metals on plants, Chemia-Dydaktyka-Ekologia-Metrologia, 11, 41-56.

8. Joka M., Szatyłowicz E., Ofman P. 2016. Ocena zawartości metali ciężkich w produktach fermentacji metanowej biogazowni rolniczej „Ryboły”, Civil and Environmental Engineering, 7, 233-237.

9. Kalembasa S., Symonowicz B., Kalembasa D., Malinowska L., 2003. Możliwości pozyskiwania i przeróbki biomasy z roślinami szybko rosnących (energetycznych). Materiały konferencyjne „Nowe spojrzenie na osady ściekowe". Wyd. Politechniki Częstochowskiej, 358-364.

10. Kazanowska J., Szaciło J. 2012 Analiza jaskości osadów ściekowych oraz możliwości ich przyrodniczego wykorzystania. Acta Agrophysica, 19(2), 343-353.

11. Xiang L., Chan L.C., Wong J.W.C., 2000. Removal of heavy metals from anaerobically digested sewage sludge by isolated indigenous iron-oxidizing bacteria. Chemosphere, Vol. 41, 283-287.

12. Milik J., Pasela R., Szymczak M., 2016. Ocena składu fizyko-chemiczne osadów ściekowych pochodzących z komunalnej oczyszczalni ścieków. Rocznik Ochrona Środowiska, 18(2), 579-890.

13. Rajczyk K., Giergiczny E., Szota E., 2013. Ocena możliwości wykorzystania w drogownictwie popiołów nowej generacji powstających ze spalania biomasy. Praca instytutu ceramiki i materiałów budowlanych.

14. Rozporządzenie ministra środowiska z dnia 20 stycznia 2015 r. W sprawie procesu odzysku R10. 
15. Rozporządzenie ministra środowiska $\mathrm{z}$ dnia $6 \mathrm{lu}$ tego 2015 r. W sprawie komunalnych osadów ściekowych.

16. Sadecka Z., Myszograj S., Suchowska-Kisielewicz M. 2011. Aspekty prawne przyrodniczego wykorzystania osadów ściekowych. Zeszyty Naukowe Uniwersytetu Zielonogórskiego, Inżynieria Środowiska, nr 144.

17. Siuta J., Dyguś K.H. 2013. Plony i chemizm roślin wielowariantowego doświadczenia na modelowym złożu odpadów paleniskowych energetyki węglowej. Inżynieria Ekologiczna, Nr 35, 7-31.

18. Wiater J., Horysz M. 2017. Organic waste as a substrat in biogas production, Journal of Ecological Engineering, 18(5), 226-234.

19. Wiater J., Butarewicz A. 2014. Sposoby wykorzystania osadów z Oczyszczalni Ścieków w Białymstoku. Inżynieria i Ochrona Środowiska, 17(2), 281-291.

20. Wilk M., Gworek B., 2009. Metale ciężkie w osadach ściekowych, Ochrona środowiska i Zasobów Naturalnych, 39, 40-59. 